\title{
Behaviour of albino and melanic variants of Biomphalaria glabrata Say, 1818 (Mollusca: Planorbidae) following infection by Schistosoma mansoni Sambon, 1907
}

\author{
Allegretti, SM. ${ }^{\text {a }}$, Carvalho JF. ${ }^{\mathrm{b}}$, Magalhães, $L A .^{\mathrm{a}}$ \\ and Zanotti-Magalhães, EM. ${ }^{\text {** }}$

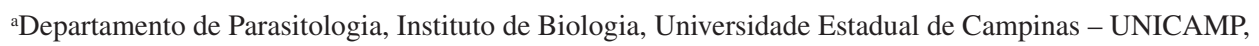 \\ Cidade Universitária, Barão Geraldo, CP 6109, CEP 13083-970, Campinas, SP, Brazil \\ 'Statistika Consultoria \\ Rua Barão de Jaguará, 1481, Ed. Cruz Alta, 14ª andar, Sala 47, Centro, CEP 13015-910 Campinas, SP, Brazil \\ *e-mail: emzm@unicamp.br \\ Received January 28, 2008 - Accepted May 5, 2008 - Distributed February 28, 2009
}

\begin{abstract}
The behaviour of the albino and melanic variants of Biomphalaria glabrata of Belo Horizonte (MG. Brazil) was studied comparatively, in terms of their respective susceptibilities to infection by Schistosoma mansoni of the same origin, through observation of the elimination of cercariae for a three-month period and the calculation of mortality and infection rates, in control and in infected snails. The number of amoebocytes, granulocytes and hyalinocytes in the circulating hemolymph during different periods of infection was analyzed. The evolution of the infection in the tissues was observed by means of histological cross-sections. The melanic variant showed greater susceptibility to infection and a higher mortality rate. The albino variant showed a higher number of circulating amoebocytes, both granulocytes and hyalinocytes. A higher number of degenerated sporocysts were seen in the histological cross-sections of the albino variant. The results suggest that the melanic variant of B. glabrata was more susceptible to infection by $S$. mansoni than was the albino variant.
\end{abstract}

Keywords: Biomphalaria glabrata, amoebocytes, Schistosoma mansoni, sporocysts.

\section{Comportamento de Biomphalaria glabrata variantes albina e melânica frente à infecção pelo Schistosoma mansoni}

\section{Resumo}

Foi estudado comparativamente o comportamento das variantes albina e melânica de Biomphalaria glabrata de Belo Horizonte (MG. Brasil), em relação à susceptibilidade à infecção pelo Schistosoma mansoni de mesma origem, através da observação da eliminação de cercárias por um período de três meses e a verificação das taxas de mortalidade e infecção nos moluscos controles e infectados. Analisou-se também, o número de amebócitos granulócitos e hialinócitos na hemolinfa circulante em diferentes períodos de infecção. A evolução da infecção nos tecidos foi observada através de cortes histológicos. A variante melânica apresentou maior susceptibilidade à infecção e maior taxa de mortalidade. A variante albina apresentou maior número de amebócitos circulantes, tanto granulócitos quanto hialinócitos. Nos cortes histológicos foi verificado maior número de esporocistos degenerados na variedade albina. Por estes resultados sugere-se que nas populações estudadas a variante melânica de $B$. glabrata, foi mais susceptível à infecção pelo S. mansoni.

Palavras-chave: Biomphalaria glabrata, amebócitos, Schistosoma mansoni, esporocistos.

\section{Introduction}

Susceptibility or resistance to infection in planorbid snails by $S$. mansoni is regulated genetically in a way that some susceptibility may be present in resistant snails (Richards and Merritt, 1972; Richards, 1973; Carton et al., 2005).

Populations of snails of the same species show different degrees of susceptibility to infection (Paraense and Corrêa, 1963). Loker and Bayne (1982) ascertained that the great majority of sporocysts incubated in the plasma of susceptible snails and later put into contact with amoebocytes originating from resistant snails were destroyed. When the sporocysts were incubated in plasma from resistant snails and later exposed to amoebocytes of susceptible snails, no destruction of the larvae was noted. Bayne et al. (1986) noted that sporocysts exposed to the plasma of resistant snails showed changes in their antigenicity. It may be that the sporocysts become covered with components of the plasma from the host, masking the possibility of its 
being recognized by the snail's defense system. Among the components found in the plasma of planorbids are lectin, lysin, agglutinin and substances similar to lymphocin, hydrogen peroxide, as well as other microbian factors (Lie et al., 1980; Boswell and Bayne, 1986; Connors and Yoshino, 1990; Castillo and Yoshino, 2002). Tripp (1974) and Abdul Salam and Michelson (1980) observed that the ability of granulocyte to stick to glass and spread out depends on factors existing in the plasma. Martins-Souza et al. (2006) suggest that the binding of different lectins to the amoebocytes may have some correlation with the susceptibility or resistance to the parasite.

Many observations have been made about cellular and humoral interactions. Granath and Yoshino (1984); Hahn et al. (2001); noted that when sporocysts are incubated in hemolymph containing amoebocytes and plasma, or when they are incubated only with amoebocyte, they were destroyed. But, when they were incubated only with plasma, they were not destroyed. Balan et al. (1993) did not find an amoebocitary reaction around degenerated sporocysts, suggesting that factors of the plasma might be involved in the cases.

Other factors that determine both cellular and humoral reactions are not very well known, nor are the genetic components involved. It is certain that the ages of the snails are major factors (Newton, 1953; Wright and Ross, 1963; Richards, 1973, Richards, 1984; Loker et al., 2004).

The present article describes research carried out on the influence of the melanic component on the susceptibility of snails to infection by $S$. mansoni of the $\mathrm{BH}$ lineage and in the immune response mechanism involving amoebocytes. Albino populations of snails are often used to maintain S. mansoni in laboratories, whereas in nature, melanic populations are more common. In this study, Biomphalaria glabrata snails of the albino and melanic variants from Belo Horizonte, State of Minas Gerais, Brazil, were used. The rates of infection were studied, as well as the elimination of cercariae, the numbers of amoebocytes in the circulating hemolymph, and the amoebocitary reactions in the tissue of the infected snails.

\section{Material and Methods}

In the experiments, albino and melanic variants of B. glabrata snails were used. They descended from populations from Belo Horizonte, Brazil, and were ceded by Dr. Wladimir Lobato Paraense, of the Oswaldo Cruz Institute. These snails were kept in the vivarium at the Parasitology Department of the State University at Campinas (UNICAMP), State of São Paulo, Brazil.

The following experimental groups were studied:

1) 50 albino snails and 50 melanic snails exposed individually to 10 miracidia of $S$. mansoni of the BH strain. These snails were used to obtain the infection rate, the pre-patent period, the period of elimination of cercariae, and the mortality rate.

2) 50 albino snails and 50 melanic snails that had not been exposed to $S$. mansoni (controls) were used to observe their mortality rate.
3) 77 albino snails and 77 melanic snails exposed individually to 10 miracidia of $S$. mansoni were used to observe the number of amoebocytes in the hemolymph.

4) 77 albino snails and 77 melanic snails not exposed to infection (control) were used to observe the number of amoebocytes in the hemolymph.

5) 15 albino snails and 15 melanic snails exposed to 100 miracidia of $S$. mansoni were used to observe the larvae in the tissues of the snails.

To determine the rate of infection by $S$. mansoni the snails in Group 1 were observed weekly for 13 weeks. The same procedure was carried out in order to calculate the pre-patent period, the period of elimination of cercariae, and the snails' mortality rates.

The presence of sporocysts, as seen through a stereoscopic microscope, was used as a criterion for detecting the infected snails and their elimination of cercariae.

We used the snails in Groups 3 and 4 to count the amoebocytes in the circulating hemolymph. Subgroups of 7 snails were counted after 30 minutes, and at 1, 2, 4, $6,8,10,12,24,48$ and 72 hours following exposure to the miracidia.

Hemolymph was removed from the snails by puncturing the cephalopodal region with a Pasteur pipette. The snails used for extraction measured from $5 \mathrm{~mm}$ to $9 \mathrm{~mm}$ in diameter.

A Neubauer chamber, where the hemolymph was placed immediately following extraction, was used to count the amoebocytes. The count was carried out under a contrast and phase microscope and the amoebocytes were classified into granulocytes and hyalinocytes.

The planorbids in Group 5 were used to observe the larvae in the tissues of the snails. The serial histological cuts of these animals were examined in preparations made in subgroups of 3 snails killed at 30 minutes, and at 2, 24, 48 and 72 hours after infection.

The histological preparations were colored by Gomori trichromic (Guaraldo et al., 1981).

Statistical analysis was carried out using the SAS ${ }^{\circledast}$ (Statistical Analysis System) program. By means of this analysis, the differences in susceptibility to the infection and the mortality rate of the snails in the various weeks of observation were evaluated by the Catmod method.

The values obtained from counting the cells of the hemolymph were studied statistically through variance analysis with factorial treatment $\times$ time for each type of snail.

The types of sporocysts seen in the tissues of the snails were analyzed quantitatively, using the method of comparison of two independent proportions.

\section{Results}

Sporocysts were seen (by macroscopic examination) in the cephalopodal region of the snails as of the first week after exposure of the snails to the miracidia. 
The melanic snails began eliminating cercariae during the fourth week after infection (Tables 1 and 2). Thirty-six percent of the melanic snails exposed to the miracidia showed elimination of cercariae. During the fourth week, $72 \%$ of the live snails eliminated cercariae. This number fell to $18 \%$ (60\% of the living snails) during the seventh week and, during the final three weeks, $8 \%$ of the infected snails ( $44 \%$ of those surviving) were eliminating cercariae.

The albino variant started eliminating cercariae during the fifth week after exposure to the miracidia, the infection rate for this group being $24 \%$ (Table 1). During the fifth week, $44 \%$ of the surviving albino snails (Table 2) eliminated cercariae. During the seventh week the number was $31.82 \%$. In the ninth week it was $15 \%$ and, during the tenth, $5.56 \%$ (Table 2). After the tenth week no more elimination of cercariae was noted.

The melanic snails showed a shorter pre-patent period than the albino snails (Table 2).

The mortality rate of the snails exposed to infection is shown in Table 3. Throughout the experiment, the highest mortality rate was among the infected melanic snails.

Table 4 shows the numbers of circulating amoebocytes in the hemolymph of the snails in the various groups and times of infection. The cells were classified

Table 1. Infection rates of albino and melanic variants of B. glabrata after 13 weeks of exposure to 10 miracidia of $S$. mansoni BH strain.

\begin{tabular}{lccc}
\hline B. glabrata & $\begin{array}{c}\text { Number } \\
\text { of infected } \\
\text { snails }\end{array}$ & $\begin{array}{c}\text { Number } \\
\text { of snails } \\
\text { releasing } \\
\text { cercariae }\end{array}$ & $\begin{array}{c}\text { Infection } \\
\text { rate } \\
(\%)\end{array}$ \\
\hline Albino & 50 & 12 & 24.0 \\
Melanic & 50 & 18 & 36.0 \\
\hline
\end{tabular}

into granulocyte and hyalinocyte. An increase in the number of granulocyte amoebocytes in the albino variant was seen during the first hours of infection, with maximum peak being 12 hours after infection, with a gradual decrease until 48 hours and then a further increase at 72 hours. A general trend toward increase was seen in melanic variant during the first hours after infection, and then there was a fall in the number of amoebocytes until 48 hours.

Table 5 shows the numbers referring to the examination of the larvae of $S$. mansoni in the cross sections of the snails. As of the first hours following infection, degenerated larvae were seen in both variants, surrounded by slight amoebocitary reaction. Forty-eight hours following infection a significantly higher number of degenerated sporocysts were seen in the albino variant. The proportion of viable sporocysts found during the various periods of observation was significantly higher for the melanic variant $(\mathrm{P}>0.01)$.

\section{Discussion}

The variations in the patterns of pigmentation in the mantle of the snails are genetically determined and might be influencing the susceptibility of the snails to infection by $S$. mansoni. This hypothesis was not proven by either Richards and Merritt (1972) or by Richards (1973), who were interested in studying this aspect. Through numerous crossings between resistant and susceptible snails, these latter authors, using self-fecundation, concluded that susceptibility or refractiveness results from a broad variability of genes, and are not related to pigmentation.

In the present experiment, different susceptibility rates and mortality rates were seen in the albino and melanic variants of the snails studied. The susceptibility and mortality rates were significantly higher in the melanic snails, and rose especially as of the fourth week, when

Table 2. Infection of albino and melanic variants of B. glabrata exposed to $S$. mansoni.

\begin{tabular}{|c|c|c|c|c|c|c|}
\hline \multirow{2}{*}{$\begin{array}{l}\text { Period } \\
\text { (weeks) }\end{array}$} & \multicolumn{3}{|c|}{ B. glabrata melanic } & \multicolumn{3}{|c|}{ B. glabrata albino } \\
\hline & $\begin{array}{c}\text { Number of live } \\
\text { snails }\end{array}$ & $\begin{array}{c}\text { Number of } \\
\text { positive snails }\end{array}$ & $\begin{array}{c}\text { Infection rate } \\
(\%)\end{array}$ & $\begin{array}{c}\text { Number of } \\
\text { live snails }\end{array}$ & $\begin{array}{c}\begin{array}{c}\text { Number of } \\
\text { positive snails }\end{array} \\
\end{array}$ & $\begin{array}{c}\text { Infection rate } \\
(\%)\end{array}$ \\
\hline 1 & 45 & 0 & 0.00 & 50 & 0 & 0.00 \\
\hline 2 & 45 & 0 & 0.00 & 50 & 0 & 0.00 \\
\hline 3 & 40 & 0 & 0.00 & 50 & 0 & 0.00 \\
\hline 4 & 25 & 18 & 72.00 & 40 & 0 & 0.00 \\
\hline 5 & 25 & 18 & 72.00 & 27 & 12 & 44.44 \\
\hline 6 & 25 & 18 & 72.00 & 27 & 12 & 44.44 \\
\hline 7 & 15 & 9 & 60.00 & 22 & 7 & 31.82 \\
\hline 8 & 15 & 9 & 60.00 & 21 & 7 & 33.33 \\
\hline 9 & 12 & 6 & 50.00 & 20 & 3 & 15.00 \\
\hline 10 & 10 & 5 & 50.00 & 18 & 1 & 5.56 \\
\hline 11 & 9 & 4 & 44.44 & 16 & 0 & 0.00 \\
\hline 12 & 9 & 4 & 44.44 & 16 & 0 & 0.00 \\
\hline 13 & 4 & 9 & 44.44 & 14 & 0 & 0.00 \\
\hline
\end{tabular}


Table 3. Mortality of albino and melanic variants of B. glabrata exposed or not (control) to S. mansoni

\begin{tabular}{|c|c|c|c|c|c|c|c|c|}
\hline \multirow{3}{*}{$\begin{array}{l}\text { Period } \\
\text { (weeks) }\end{array}$} & \multicolumn{4}{|c|}{ B. glabrata melanic } & \multicolumn{4}{|c|}{ B. glabrata albino } \\
\hline & \multicolumn{2}{|c|}{ Control } & \multicolumn{2}{|c|}{ Infected } & \multicolumn{2}{|c|}{ Control } & \multicolumn{2}{|c|}{ Infected } \\
\hline & $\begin{array}{l}\text { Number of } \\
\text { dead snails }\end{array}$ & $(\%)$ & $\begin{array}{l}\text { Number of } \\
\text { dead snails }\end{array}$ & $(\%)$ & $\begin{array}{l}\text { Number of } \\
\text { dead snails }\end{array}$ & $(\%)$ & $\begin{array}{l}\text { Number of } \\
\text { dead snails }\end{array}$ & $(\%)$ \\
\hline 1 & 1 & 2.00 & 5 & 10.00 & 0 & 0.00 & 0 & 0.00 \\
\hline 2 & 2 & 4.00 & 5 & 10.00 & 0 & 0.00 & 0 & 0.00 \\
\hline 3 & 5 & 10.00 & 10 & 20.00 & 0 & 0.00 & 0 & 0.00 \\
\hline 4 & 5 & 10.00 & 25 & 50.00 & 3 & 6.00 & 10 & 20.00 \\
\hline 5 & 5 & 10.00 & 25 & 50.00 & 5 & 10.00 & 23 & 46.00 \\
\hline 6 & 5 & 10.00 & 25 & 50.00 & 5 & 10.00 & 23 & 46.00 \\
\hline 7 & 7 & 14.00 & 35 & 70.00 & 5 & 10.00 & 28 & 56.00 \\
\hline 8 & 7 & 14.00 & 35 & 70.00 & 5 & 10.00 & 29 & 58.00 \\
\hline 9 & 16 & 32.00 & 38 & 76.00 & 5 & 10.00 & 30 & 60.00 \\
\hline 10 & 20 & 40.00 & 40 & 80.00 & 8 & 16.00 & 32 & 64.00 \\
\hline 11 & 22 & 44.00 & 41 & 82.00 & 8 & 16.00 & 34 & 68.00 \\
\hline 12 & 23 & 46.00 & 41 & 82.00 & 14 & 28.00 & 34 & 68.00 \\
\hline 13 & 23 & 46.00 & 41 & 82.00 & 14 & 28.00 & 36 & 72.00 \\
\hline
\end{tabular}

Table 4. Means of amoebocytes in albino and melanic variants of B. glabrata infected by S. mansoni.

\begin{tabular}{|c|c|c|c|c|}
\hline \multirow{2}{*}{$\begin{array}{l}\text { Infection period } \\
\text { (hours) }\end{array}$} & \multicolumn{2}{|c|}{ Granulocytes $^{1}\left({\left.\text { cells} / \mathbf{m m}^{3}\right)}^{3}\right.$} & \multicolumn{2}{|c|}{ Hyalinocytes $^{1}\left(\right.$ cells/mm $\left./ \mathbf{m m}^{3}\right)$} \\
\hline & Albino & Melanic & Albino & Melanic \\
\hline Control $^{2}$ & $3.0 \pm 2.6$ & $2.6 \pm 2.1$ & $12.7 \pm 15.8$ & $4.3 \pm 5.4$ \\
\hline 0.5 & $1.4 \pm 2.0$ & $2.1 \pm 1.6$ & $5.4 \pm 5.4$ & $2.1 \pm 1.7$ \\
\hline 1 & $1.7 \pm 2.0$ & $0.3 \pm 0.5$ & $9.4 \pm 4.9$ & $5.3 \pm 3.4$ \\
\hline 2 & $2.7 \pm 2.2$ & $3.4 \pm 2.4$ & $3.7 \pm 2.4$ & $11.4 \pm 8.5$ \\
\hline 4 & $5.1 \pm 2.8$ & $2.7 \pm 2.3$ & $16.1 \pm 14.1$ & $6.4 \pm 3.7$ \\
\hline 6 & $3.6 \pm 2.8$ & $1.6 \pm 1.4$ & $6.9 \pm 8.5$ & $10.3 \pm 9.9$ \\
\hline 8 & $3.6 \pm 2.6$ & $3.7 \pm 1.4$ & $11.0 \pm 5.3$ & $16.0 \pm 9.1$ \\
\hline 10 & $5.0 \pm 1.4$ & $1.0 \pm 1.1$ & $12.4 \pm 4.6$ & $11.0 \pm 6.5$ \\
\hline 12 & $7.9 \pm 6.0$ & $2.6 \pm 1.8$ & $20.1 \pm 11.3$ & $21.9 \pm 16.5$ \\
\hline 24 & $3.6 \pm 2.1$ & $4.3 \pm 3.7$ & $14.4 \pm 6.0$ & $11.7 \pm 7.1$ \\
\hline 48 & $1.6 \pm 1.6$ & $1.6 \pm 0.9$ & $9.0 \pm 6.7$ & $10.4 \pm 9.5$ \\
\hline 72 & $4.0 \pm 2.2$ & $1.4 \pm 1.3$ & $16.0 \pm 11.5$ & $3.6 \pm 2.3$ \\
\hline
\end{tabular}

${ }^{1}$ Means of amoebocytes in the hemolymph of 7 snails for each period. ${ }^{2}$ Snails without infection.

Table 5. Means of S. mansoni larvae observed in albino and melanic variants of B. glabrata exposed to 100 miracidia $(n=3)$.

\begin{tabular}{|c|c|c|c|c|c|c|}
\hline \multirow{2}{*}{$\begin{array}{c}\text { Infection } \\
\text { period } \\
\text { (hours) }\end{array}$} & \multicolumn{3}{|c|}{ Albino } & \multicolumn{3}{|c|}{ Melanic } \\
\hline & Viable & Degenerated & Total & Viable & Degenerated & Total \\
\hline 0.5 & $27.3 \pm 2.1$ & $26.7 \pm 1.7$ & $54.0 \pm 0.8$ & $42.0 \pm 9.6$ & $34.0 \pm 4.3$ & $76.0 \pm 12.0$ \\
\hline 2 & $17.3 \pm 5.4$ & $14.3 \pm 3.3$ & $31.6 \pm 2.6$ & $21.0 \pm 6.5$ & $27.6 \pm 2.0$ & $48.6 \pm 4.9$ \\
\hline 24 & $12.3 \pm 4.2$ & $10.3 \pm 7.4$ & $22.6 \pm 11.6$ & $31.3 \pm 3.4$ & $20.0 \pm 6.5$ & $51.3 \pm 9.8$ \\
\hline 48 & $10.0 \pm 1.4$ & $6.3 \pm 4.2$ & $16.3 \pm 5.6$ & $27.7 \pm 5.6$ & $24.3 \pm 6.6$ & $52.0 \pm 12.0$ \\
\hline 72 & $5.7 \pm 2.5$ & $18.7 \pm 3.3$ & $24.4 \pm 5.8$ & $24.3 \pm 7.6$ & $15.7 \pm 4.9$ & $40.0 \pm 9.1$ \\
\hline
\end{tabular}


the cercariae began being released. The higher mortality rate seen in these melanic snails may have been the consequence of the damage caused directly by the parasitism, or by the effect of the toxin developed by the parasites, or due to the spoiling action of the larvae.

The pre-patent period was shorter in the group of melanic snails. The albino snails ceased eliminating cercariae before the melanic snails did.

Hyalinocytes predominated in the hemolymph of both variants of B. glabrata. Sminia and Knaap (1987) and Seta et al. (1996) obtained the same result.

Analyzing the number of granulocytes in the hemolymph, a significant difference was seen between the two variants. The albino variant showed a significantly higher number of cells that emit pseudopods.

We saw that there was a reduction in the number of cells in the hemolymph of both the albino and the melanic variants during the first hours, followed by a significant increase after 12 hours in the albino variant and after 24 hours in the melanic variant. Stumpf and Gilbertson (1978) and Seta et al. (1996) observed an abrupt increase in circulating cells in hemolymph after exposure of the snails to the miracidia of $S$. mansoni. This phenomenon was not seen in the present experiment. Our results are similar to those of Santana (1990), who noted that the peak number of amoebocytes in the hemolymph occurred 24 hours after exposure to the miracidia. These results also correspond to the observations made by Matricon Gondran et al. (1986), who saw considerable mitotic activity in the Amoebocyte Producing Organ (APO) during the first 48 hours after infection of $B$. glabrata infected previously with Echinostoma caproni. The maximum increase not did occur immediately after infection.

The late increase in granulocytes seen after 12 hours in the albino variant and 24 hours in the melanic variant leads us to believe that the amoebocytes migrated to the tissues in an attempt to combat the infection and returned later to the circulating hemolymph after several hours. These increases seen in both variants may be due to three factors: 1) a return of the amoebocyte from the tissues to the hemolymph; 2) a production of new cells by the APO; 3) a combination of these two factors. The APO may have been stimulated to produce more cells during the first 48 hours after infection (Barbosa et al., 2006).

The fact that there were more granulocytes in the albino snails can be explained by the fact that these snails showed more resistance to infection.

Upon examination of the tissues of the snails of both variants, a higher number of larvae were seen during the first periods observed. This leads the authors to believe that the fewer number of larvae found after 72 hours of infection may be the consequence of the destruction and elimination of larvae by the snails' defense mechanisms.

The total number of degenerated sporocysts found in the tissues during all the periods observed was higher in the albino variant. Higher numbers of viable sporocysts were found in the melanic variant.
This study shows the role played by hemocytes in the albino and melanic variants of B. glabrata through the cynetics of these cells in the circulation and in the tissues of the snails. The presence of degenerate sporocysts surround by a slight amoebocitary reaction shortly after infection (30 minutes, and 2 hours) might lead to the conclusion that soluble factors may be involved. Evidence of the action of the amoebocytes and the participation of different lectins in binding the larvae of the trematode with the amoebocytes (Martins-Souza et al., 2006) can be tested by the technique of cultures of the amoebocyte producing organ (APO) as first described by Barbosa et al. (2006).

The results of the observation of the histological cross-sections seem to correlate with the numbers of cells seen in the hemolymph during the same periods after infection. A high number of degenerated sporocysts were observed during the first hours after infection. This observation coincided with the number of cells in the circulating hemolymph, where a small number of cells were seen during the first hours after infection, indicating that the amoebocyte might be in the tissues. Twentyfour hours following infection there was a high increase in the number of cells in the circulating hemolymph in the melanic variant. At this same moment, a greater number of viable sporocysts than degenerated sporocysts were observed, indicating that during this period the amoebocytes were not involved in the combat against the larvae.

These results are similar to those obtained by Guaraldo et al., 1981, Hahn et al., 2001, who studied the reactions of tissues in B. glabrata and B. tenagophila Orbigny, 1835 (Mollusca: Planorbidae) from the first hours until the eighth week following infection, observing that there was slight amoebocitary reaction around the sporocysts in B. glabrata, whereas there was a strong reaction of the tissues in $B$. tenagophila.

Our research showed a significantly higher number of degenerated sporocysts after 72 hours of infection in the albino, than in the melanic variant. This finding was considered significant because, after 72 hours of infection, the most intense tissue reactions had already taken place. The albino snails showed a more efficient system for combating the schistosomotic infection.

It should be remembered that Martins-Souza et al. (2006) detected different lectins binding to the amoebocytes, with strong indications of a correlation with the susceptibility or resistance of the snails to $S$. mansoni. Does the biochemistry of the production of melanin by the melanocytes in the melanic variant of B. glabrata interfere in the snails' defense mechanisms?

The results suggest that the melanic variant of the B. glabrata population studied was more susceptible to S. mansoni than the albino variant, and that mechanisms of the snails' internal defense system are most likely involved in the greater resistance shown by the albino variant. 


\section{References}

ABDUL-SALAM, J.M. and MICHELSON, E.H., 1980. Biomphalaria glabrata amebocytes: effect of Schistosoma mansoni infection on in vitro phagocytosis. J. Invertebr. Pathol., vol. 35 , no. 3 , p. $241-248$.

BALAN, D.S.L, MAGALHÃES, L.A. and PIEDRABUENA, A.E., 1993. Aspectos imunológicos e parasitológicos em Biomphalaria tenagophila infectadas por Schistosoma mansoni e outros Digenea. Rev. Saúde Pública, vol. 27, no. 6, p. $21-429$

BARBOSA, L., SILVA, L.M., COELHO, P.M.Z., SANTOS, S.R. and FORTES-DIAS, C.L., 2006. Primary culture of the region of the amebocyte-producing organ of the snail Biomphalaria glabrata, the intermediate host of Schistosoma mansoni. Mem. Inst. Oswaldo Cruz, vol. 101, no. 6, p. 639-643.

BARBOSA, L., CALDEIRA, R.L., CARVALHO, O.S., VIDIGAL, T.H.D.A., JANNOTTI-PASSOS, L.K. and COELHO, P.Z., 2006. Resistance to Schistosoma mansoni by transplantation of APO Biomphalaria tenagophila. Parasite Immunol., vol. 28 , no. 5, p. 209-212.

BAYNE, C.J., LOKER, E.S. and YUI, M.A., 1986. Interactions between the plasma proteins of Biomphalaria glabrata (Gastropoda) and the sporocyst tegument of Schistosoma mansoni (Trematode). Parasitol., vol. 92, no. 3, p. 653-664.

BOSWELL, C.A. and BAYNE, C.J., 1986. Lectin-dependent cell-mediated cytotoxicity in an invertebrate model: Con A does not act as bridge. Immunology., vol. 57, no. 2, p. 261-264.

CARTON, Y., NAPPI, A.J. and POIRIE, M., 2005 Genetics of anti-parasite resistance in invertebrates. Dev. Comp. Immunol., vol. 29 , no. 1, p. 9-32.

CASTILlO, M.G. and YOSHINO, T.P., 2002. Carbohydrate inhibition of Biomphalaria glabrata embryonic (Bge) cell adhesion to primary sporocysts to Schistosoma mansoni. Parasitology., vol.125 (Pt 6), no. 6, p. 513-525.

CONNORS, V.A. and YOSHINO, T.P., 1990. In vitro effect of larval Schistosoma mansoni excretory-secretory products on phagocytosis-stimulated superoxide production in hemocytes from Biomphalaria glabrata. J. Parasitol., vol. 76, no. 6, p. $895-902$

GRANATH Jr., W.O. and YOSHINO, T.P., 1984. Schistosoma mansoni: passive transfer of resistance by serum in the vector snail, Biomphalaria glabrata. Exp. Parasitol., vol. 58, no. 2, p. $188-193$

GUARALDO, A.M.A., MAGALHÃES, L.A., RANGEL, H.A. and PAREJA, G., 1981. Evolução dos esporocistos de Schistosoma mansoni Sambon, 1907, em Biomphalaria glabrata (Say, 1818) e Biomphalaria tenagophila (D'Orbigny, 1835). Rev. Saúde Pública, vol. 15, no. 4, p. 436-448.

HAHN, U.K., BENDER, R.C. and BAYNE, C.J., 2001. Killing of Schistosoma mansoni sporocysts by hemocytes from resistant Biomphalaria glabrata: role of reactive oxygen species. $J$. Parasitol., vol. 87, no. 2, p. 292-299.

LIE, K.J., JEONG, K.H. and HEYNEMAN, D., 1980. Tissues reactions induced by Schistosoma mansoni in Biomphalaria glabrata. Ann. Trop. Med. Parasitol., vol. 74, no. 2, p. 157-166.

LOKER, E.S. and BAYNE, C.J., 1982. In vitro encounters between Schistosoma mansoni primary sporocysts and hemolymph components of susceptible and resistant strains of
Biomphalaria glabrata. Am. J. Trop. Med. Hyg., vol. 31, no. 5, p. $999-1005$.

LOKER, E.S., ADEMA, C.M., ZHANG, S.M. and KEPLER, T.B. 2004. Invertebrate immune systems - not homogeneous, not simple, not well understood. Immunol. Rev., vol. 198, no. 1, p. 10-24.

MARTINS-SOUZA, R.L., PEREIRA, C.A.J., MARTINS FILHO, A.O., COELHO, P.M.Z., CORRÊA Jr., A. and NEGRÃO-CORRÊA，D. 2006. Differential lectin labelling of circulanting hemocytes from Biomphalaria glabrata and Biomphalaria tenagophila resistant or suceptible to Schistosoma mansoni infection. Mem. Inst. Oswaldo Cruz., vol. 101, suppl. I, p. 185-192.

MATRICON-GONDRAN, M., JOKE, A. and BENEX, J., 1986. Responses of the amebocytes producing organ (APO) in Biomphalaria glabrata susceptible or resistant to trematode invasion: an ultrastructural study. Dev. Comp. Immunol., vol. 10, no. 4 , p. 636

NEWTON, W.L., 1953. The inheritance of susceptibility to infection with Schistosoma mansoni in Australorbis glabratus. Exp. Parasitol, vol. 2, no. 3, p. 242-257.

PARAENSE, W.L. and CORRÊA, L.R., 1963. Variation in susceptibility of populations of Australorbis glabratus to a strain of Schistosoma mansoni. Rev. Inst. Med. Trop. São Paulo, vol. 5 , no. 1 , p. 15-22.

RICHARDS, C.S. and MERRITT, J.W., 1972. Genetic factors in the susceptibility for juvenile Biomphalaria glabrata to Schistosoma mansoni infection. Am. J. Trop. Med. Hyg., vol. 21, no. 4 , p. 425-434.

RICHARDS, C.S., 1973. Susceptibility of adult Biomphalaria glabrata to Schistosoma mansoni infection. Am. J. Trop. Med. Hyg., vol. 22, no. 6, p. 748-756.

-, 1984. Influence of snail age one genetic variations in susceptibility of Biomphalaria glabrata for infections with Schistosoma mansoni. Malacologia, vol. 25, no. 2, p. 493-502.

SANTANA, J.V., 1990. Mecanismo de defesa em Biomphalaria tenagophila e Biomphalaria glabrata frente ao Schistosoma mansoni. Campinas: Universidade Estadual de Campinas. (Tese de doutorado).

SETA, L., MAGALHÃES, L.A. and CARVALHO, J.F., 1996. Comportamento dos amebócitos circulantes de moluscos planorbídeos frente ao parasitismo por larvas de Schistosoma mansoni, à inoculação de tinta Nanquin ou à fratura da concha. Rev. Saúde Publ., vol. 30, no. 4, p.332-340.

SMINIA, T. and VAN KNAAP, W.P.W., 1987. Cells and molecules in molluscan immunology. Dev. Comp. Immunol., vol. 11, no. 1, p.17-28.

STUMPF, J.L. and GILBERTSON, D.E., 1978. Hemocytes of Biomphalaria glabrata: Factor affecting variability. J. Invert. Pathol., vol. 32, no. 2, p. 177-181.

TRIPP, M.R., 1974. Molluscan immunity. Ann. Acad. N.Y. Sci., vol. 234 , no. 1 , p. $23-27$.

WRIGHT, C.A. and ROSS, G.C., 1963. Electrophoretic studies of blood and egg proteins in Australorbis glabratus (Gastropoda, Planorbidae). Ann. Trop. Med. Parasit., vol. 57, no. 1, p. 47-51. 